\title{
UTAK ÉS ZSÁKUTCÁK A BÜROKRÁCIA CSÖKKENTÉSÉRE *
}

\author{
Agócs-Kiss János ${ }^{1}$
}

Csapataink harcban állnak ${ }^{2}$ - most épp a bürokrácia jelensége ellen. Tegyünk egy rövid áttekintést, hogy kiderüljön mi a jelenlegi állása a küzdelemnek. Jelen irásnak nem célja, hogy értékelje, jó-e a bürokrácia, vagy hasznos-e az ellene folytatott küzdelem. A szerzö meggyözödése, hogy a jelenlegi, bürokratikus ügyintézés egyszerüsitése a jogtudomány és a technika mai állása alapján megtehető, söt a közigazgatás egyik legnagyobb aktuális kihívása.

A bürokráciát, mint a jogalkalmazás egyik sajátos jelenségét már nagyon sokan - köztük e folyóiratban korábban közzétett írásokban is - elemezték, pozitív és negatív színben feltüntetve, de pontos meghatározása még nem született. ${ }^{3}$ Erre nem is kívánok most kísérletet tenni, pusztán egy-egy elemét emelem ki, jelen vizsgálatom céljából: bürokratikusnak tekinthetjük a közigazgatási eljárást, ha az ügyfélnek a szükségesnél - általában egynél - több alkalommal kell a hatósággal személyesen, vagy más formában interakcióba lépnie, vagy ha a döntéshez a szükségesnél több adatot kell rendelkezésre bocsátania. Hiszen ezekben az esetekben nem hatékony az interakció, illetve a közigazgatási szervvel felesleges információkat is közölni kell. Szintén a bürokrácia jellemzöje lehet az is, ha egy adott ténybeli helyzet - például új gazdasági társaság megalapítása, és a müködéséhez elengedhetetlen engedélyek megkérése - több hatóság párhuzamos megkeresését teszi szükségessé, illetve ezek újabb közigazgatási eljárásokat, vagy intézkedéseket generálnak.

Ugyanakkor a bürokrácia jelentkezhet az eljárás másik oldalán, a közigazgatási szervek közötti interakciókban is. Ha az igazgatási szervek közötti információáramlás esetleges, vagy többlépcsős, vagy felesleges elemeket tartalmaz, akkor az érintett igazgatási egységek ügyintézése is elnehezül, hatékonytalanná válik.

\footnotetext{
${ }^{*}$ DOI 10.21867/KjK/2018.2.3.

${ }^{1}$ Dr. Agócs-Kiss János, óraadó, DE ÁJK; PhD hallgató, Marton Géza Állam- és Jogtudományi Doktori Iskola

2 A tanulmány alapjául szolgáló kutatás a Magyar Tudományos Akadémia és a Debreceni Egyetem Állam- és Jogtudományi Kar közös, MTA-DE Közszolgáltatási Kutatócsoportjának "Az állami szabályozó szerepek újraértékelődése a szolgáltatásokban" c. projektje keretében készült. A projektirány elhelyezésére 1.: Horváth M. Tamás és Bartha Ildikó (2016) Az ágazati közszolgáltatások rendszertanáról. In: uők.(szerk.) Közszolgáltatások megszervezése és politikái. Merre tartanak? Budapest: Dialóg Campus, 25-37. old.

${ }^{3}$ Lásd: Józsa Zoltán - Bartha Ildikó (2017): A bürokrácia, barát vagy ellenség? Közjavak, III. évf. 2017/2. szám, 3-7. old.
} 
A magyar kormányzat igyekezett már több alkalommal lépéseket tenni a bürokrácia csökkentése érdekében, ezek egyik eleme volt a T/10096. számú törvényjavaslat, mely a közigazgatási bürokráciacsökkentés keretében egyes adminisztratív kötelezettségek megszüntetésével összefüggő törvénymódosításokról szóló 2016. évi XXXII. törvény formájában vált jogszabállyá 2016 második felében.

A törvény deregulációs rendelkezései mellett - melyek megannyi jogszabályt helyeznek hatályon kívül, hivatkozva azok nem alkalmazására - negyven pontban foglalja össze az igazgatás legkülönbözőbb területein a hatékonyság növelésére szánt lépéseket, melyek némelyike szintén deregulációs intézkedéseket tartalmaz.

Néhány kivétellel ezek lényege, hogy ha ügyfél az egyik nyilvántartó szervnél (amely az adott adatról a közhiteles nyilvántartást vezeti) bejelentett egy adatváltozást, akkor ezen adatváltozást - kérésére - továbbítani kell egy másik olyan szerv felé is, ahol az ügyfélnek az ilyen típusú adatait (is) nyilvántartásban vezetik. Ezzel a többszörös bejelentési kötelezettség csökken, és a bejelentőnek csak egy szerv számára kell megtennie, amely továbbítja ezen adatváltozást a többi nyilvántartást vezető szerv számára is. A jogszabály általános indokolásában rögzítésre kerül, hogy ennek célja az ügyfél és hatóság közötti interakciók csökkentése. Ezzel a céllal egyébként teljes mértékben egyetérthetünk.

Első áttekintésre ez nagyszerü, hiszen az ügyfélnek kevesebb teendője van, a közigazgatás szervei feltehetően professzionálisabban elintézik egymás között a további adategyeztetést, és az egy adat átvezetésére irányuló többszörös bruttó igazgatási eljárási határidő is vélhetően rövidebbé válik. Ezen egyszerüsítést azonban a jogszabály lényegében két típusban összefoglalható módszerrel teszi meg.

Az első típus a legegyszerübb: Például az adóigazolvány vagy a TAJ számot tartalmazó hatósági igazolvány esetében, ha az kikerül a polgár birtokából, és ő az erről szóló bejelentést a rendőrség felé tette meg, akkor a rendőrségnek hivatalból - tehát a polgár külön kérése nélkül - értesítenie kell az állami adóhatóságot illetve az egészségbiztosítási szervet. Ebben az esetben a konkrétan megjelölt állami szervnek (jelen esetben a rendörégnek) nincs mérlegelési lehetősége, és pontosan meghatározásra került az az intézmény is, akit értesíteni kell.

A második szabályozási típusban - melyet a törvényhely az esetek túlnyomó részében alkalmaz - a jogszabály egy speciális szabályozási módszert vesz igénybe. Például a jogi segítségnyújtásról szóló törvény ${ }^{4}$ úgy módosul, hogy „... A (2) bekezdés szerinti bejelentés azon adatok tekintetében, amelyeket más nyilvántartás közhitelesen tartalmaz, úgy is teljesíthető, hogy az adatváltozásról

\footnotetext{
${ }^{4}$ 2003. évi LXXX. törvény (a továbbiakban Jst.)
} 
a közhiteles nyilvántartást vezető szerv - ha ezt tőle a fél kéri - a 24 . § szerinti határidőben értesíti a jogi segítségnyújtó szolgálatot." 5

Ezen szabályozási technikában két nagyobb problémát is látok: 1. Miért csak kérelemre továbbít adatot a közhiteles nyilvántartó szerv? 2. Pontosan milyen szervnek a kötelezettségét írtuk elő az adattovábbításra, és az teljesíti-e?

Az első kérdésre az indokolás - nem csak ezen konkrét példában - nem ad választ. Pusztán lehetőség, így az ügyfél aktív magatartásán, kérelmén múlik az, hogy az adatváltozás továbbításra kerüljön. A bürokráciacsökkentés lendülete itt megtörni látszik. Az igazgatás útvesztőiben egyébként sem feltétlenül tájékozott ügyféltől nem várható el, hogy tudjon erről a lehetőségéről, másrészt, ha tudomása van róla, akkor sem biztos, hogy él vele, hiszen például kétségei lehetnek ezen (továbbított) eljárás gyorsaságáról, hatékonyságáról, és inkább maga jár el az újabb ügyben. Ugyanakkor a jogszabály nem írta elő ezekben az esetekben azt sem, hogy az ügyfelet e jogáról tájékoztatni kell. Ez a hiányosság pedig könnyen odavezethet, hogy egyrészt az ügyfelek nem élnek ezzel a jogukkal, a hatóságok pedig nem tájékoztatják erről mindenáron az ügyfeleket, hiszen az ennek következtében beálló kötelezettségük többletmunkaterhet jelentene.

A megoldás ebben az esetben egyszerü lehet: az ügyfelet nem éri hátrány, ha a fenti döntési jogát elvonva a hatóságok kötelezettségévé tesszük az eljárást, feltéve hogy tudják, melyik igazgatási szervet kell értesíteni az adatváltozásról. Ezt az igazgatási szervet ugyan megjelöli a jogszabály - jelen esetben a jogi segítségnyújtó szolgálat személyében - azonban a változás bejelentés alapjául szolgáló, közhiteles nyilvántartást vezető szervnél - például személyi lakcímnyilvántartás esetén az erre feljogosított hatóságnál - jeleznie kell az adatváltozással együtt a félnek. Tehát, ha a bejelentő nem hozza például ebben az esetben az okmányiroda tudomására, hogy ő jogi segítségnyújtási eljárásában érintett, akkor ezt nem fogja az adatbejegyző szerv tudni, és így továbbítani sem tudja más nyilvántartás-vezető szervnek az adatot. További vizsgálat tárgya lehet az is, hogy az okmányiroda munkatársai - mivel a jogszabály nem az általuk rendszeresen alkalmazott jogszabályt módosította - forgatják-e az Jst.-t, hogy értesüljenek ezen új kötelezettségükről.

Eljutottunk a szabályozási modell legnagyobb problémájához. A jogszabály alkalmazásánál a legnagyobb kihívást a „más közhiteles nyilvántartásban szereplő adatokat vezető közhiteles nyilvántartó szerv" meghatározása jelentheti. Ezen szervek körét ugyanis a jogszabály nem határozza meg, tehát ezzel a jogi norma címzettjeinek körét homályosítja el. Természetesen egy közigazgatásban jártas jogalkalmazó szakembertől elvárható lenne, hogy a közhiteles nyilvántartást vezető szerveket és nyilvántartásaikat pontosan ismerje. Ha azonban ez mégsem így lenne, akkor lehet, hogy nem a „szakiban”

\footnotetext{
5 2016. évi XXXII. törvény 14. §-ának (1) bekezdéséből merített lényegi kiemelés
} 
van a hiba: A Ket.-et felváltó általános közigazgatási rendtartásról szóló törvény ${ }^{6}$ - azaz az Ákr. - ugyan meghatározza a közhiteles hatósági nyilvántartások általános ismérveit, és a közhitelességhez füződő jogkövetkezményeket, azonban elmarad a nyilvántartást vezető szervek és a nyilvántartások felsorolása.

Ezt a feladatot az egyes törvényeknek a közigazgatási hatósági eljárásokkal, az egyes közhiteles hatósági nyilvántartásokkal összefüggő, valamint egyéb törvények módosításáról szóló törvény ${ }^{7}$ végzi el. A jogszabály 96 (!) pontban összefoglalva jelöli meg a nyilvántartásokat, a vezetésükre jogosult szerveikkel együttesen. Külön megemlítendö érdeme a szabályozásnak, hogy az egyes ágazati jogszabályok módosítását úgy végzi el, hogy egyrészt az addig bevezetett nyilvántartásokat hatósági, közhiteles jelzővel látja el, másrészt pontosan meghatározza vagy pontosítja azok adattartalmát, és azt is, hogy ebből mi minősül közhitelesnek az adott nyilvántartás esetén.

Már csak egy problémát kell tisztáznunk ezzel kapcsolatban. A bürokráciacsökkentésre irányuló jogszabály valamennyi esetben közhiteles nyilvántartásokat említ, és nem hatósági közhiteles nyilvántartásokat. Ebből az következik, hogy a nem hatóság által - például cégbíróság, vagy törvényszék által vezetett nyilvántartásokra is kell alkalmazni a jogszabályt. Azaz legalább 96 hatósági közhiteles nyilvántartást, és pontosan meg nem határozott számú hatóságinak nem minősülő közhiteles nyilvántartást vezető szervet érint a változás.

Elmondhatjuk tehát, hogy a bürokrácia csökkentésére irányuló jogszabály alapkoncepciója az, hogy ha egy adat bejelentése több helyre szükséges a hatósági nyilvántartások esetén, akkor ne az ügyfél kötelezettsége legyen ennek intézése, hanem a közigazgatásé. Azonban ennek hatására csökkenne a bürokrácia? Ha a kivitelezés hatékonyabb lett volna, tehát pontosan meghatározásra kerülnek a cselekvésre kötelezett igazgatási szervek és az eljárásuk az ügyfél akaratától függetlenül kötelezö lett volna, akkor a szabályozás részben érhetett volna el eredményeket.

Ha jobban megvizsgáljuk az új szabályozást, akkor láthatjuk, hogy lényegében a korábbi, ügyfél oldalon jelentkező bürokratikus lépéseket most az igazgatási oldalra telepítette a jogalkotó. Mivel semmilyen más eszközt, intézményt nem biztosított a nyilvántartást vezető szervek részére a jogszabály, így a rendelkezésükre álló hagyományos igazgatási eszközökkel, de lényegében az ügyfél hatékonyságával járnak el a másik hivatal felé.

Pedig lenne itt egy másik, az igazgatási területre már korábban bevezetett lehetőség is: az automatikus információátadási felület.

\footnotetext{
${ }^{6}$ 2016. évi CL. törvény

7 2013. évi LXXXIV. törvény
} 
A hatósági közhiteles nyilvántartások vezetése jelenleg már kivétel nélkül valamilyen informatikai platformon valósul meg, és nem mechanikus, papír alapú nyilvántartás formájában. Természetes elvárás, hogy a jogszabályban meghatározott követelményeknek messzemenően megfelelö informatikai rendszer kerüljön kialakításra, azaz az informatikai környezetet alakítsuk ki a jogi szabályozás követelményei alapján, és ne jogi szabályozást a rendelkezésre álló informatikai eszközök és lehetőségeik mentén. Azonban ez nem jelenti azt, hogy az informatikai rendszerekben meglévő többletlehetőségeket ne lehetne kihasználni a szabályozás megalkotásakor és az ügyintézési gyakorlat módosítására.

Az informatika hajnalán már bevezetésre került EDI lényege, hogy strukturált adatok automatikus, szabványos elektronikus cseréjét teszi lehetővé kettő vagy több, számítógép vagy alkalmazás között. ${ }^{8}$ Azaz a megfelelően rendezett adatokat tartalmazó adatbázisok - ilyenek a jelenleg tárgyalt nyilvántartások is - egymással emberi beavatkozás nélkül ki tudják cserélni adataikat.

$\mathrm{Az}$ igazgatásban már a szabályozott elektronikus ügyintézési szolgáltatásokról és az állam által kötelezően nyújtandó szolgáltatásokról szóló 83/2012. (IV. 21.) Korm. rendelet bevezette ezen lehetőséget és jelenleg az elektronikus ügyintézés és a bizalmi szolgáltatások általános szabályairól szóló törvény ${ }^{9}$ tartalmazza ennek részletes szabályait. A szabályozás azonban nem teszi kötelezővé a szolgáltatás használatát, így érthetően nem is kerül minden esetben alkalmazásra.

A fent összefoglaltak alapján kijelenthetjük, hogy a szabályozás akkor lett volna inkább eredményes, ha a másik nyilvántartó szerv felé az adattovábbítást kötelezővé teszi, a szabályt alkalmazni köteles szervek körét pontosan meghatározza a jogalkotó, és egyúttal összeköti a kötelező információ átadási felület igénybevételével is, hiszen ebben az esetben ténylegesen csökkenthető lett volna a bürokratikus lépések száma, nem csak az ügyfélnél, de az igazgatási oldalon is.

\section{Zsákutcák a bürokráciacsökkentési jogszabályban}

A jogszabály módosítja az autópályák, autóutak és föutak használatáért fizetendő, megtett úttal arányos díjról szóló törvényt ${ }^{10}$ is, amely rendelkezik arról, hogy az Európai Unió normáinak ${ }^{11}$ megfelelően az útdíj szedői, szolgáltatói tevékenységet végző szervezeteket nyilvántartásba kell venni. ${ }^{12}$

\footnotetext{
${ }^{8}$ https://www.edibasics.com/what-is-edi/ (letöltés dátuma: 2018. február 7.)

9 2015. évi CCXXII. törvény

10 2013. évi LXVII. törvény

${ }^{11} \mathrm{~A}$ Bizottság az európai elektronikus útdíjszedési szolgáltatás és műszaki elemei meghatározásáról szóló, 2009. október 6-i 2009/750/EK határozatának 19. cikke.

${ }^{12}$ Lásd az idézett törvény 21 . §-ának rendelkezéseit.
} 
Ezen nyilvántartás vonatkozásában is - a korábban említett technikával elöírásra kerül, hogy az itt tárolt adatok vonatkozásában is megtehető úgy az adatváltozási bejelentés, hogy a nyilvántartott szervezet ezt egy másik közhiteles nyilvántartást vezető szerv adatváltozási bejelentésénél kéri. Idáig semmi szokatlan nincs a szabályozásban, a korábban részletezett értelmezési és végrehajtási nehézségeken kívül. Azonban ha megvizsgáljuk a jogszabály által kötelezően vezetett, és nyilvánosan közzétett nyilvántartást ${ }^{13}$, akkor láthatjuk, hogy egy, azaz egy szervezetet tartalmaz, a Nemzeti Útdíjfizetési Szolgáltató Zrt.-t. Ebből számomra egyértelmüen következik, hogy a vizsgált bürokráciacsökkentési jogszabály előkészítése nagyobb körültekintést igényelt volna. Egyetlen szervezet érdekében - ahol ráadásul ebben a konkrét esetben feltehetően felkészült jogi és igazgatási szakemberek végzik ügyfél helyzetben feladataikat, tehát professzionális ügyfélnek tekinthetjük, - teljesen felesleges a szabályozás ilyen irányú átalakítása, hiszen az összetett, nehezen értelmezhető (és az is lehet, hogy soha nem is alkalmazott) szabályok megteremtésével nem csökkentjük, hanem megszaporítjuk a bürokratikus jelenségek számát.

A zsákutcák számát növeli nézetem szerint a jogszabály azon rendelkezése is, amely a kisajátításról szóló törvényt ${ }^{14}$ módosítja. A változás lehetővé teszi a Kormányhivatalok ügyintézőinek, hogy ne rendeljenek ki ingatlanforgalmi szakértőt a kisajátítandó ingatlan értékének megállapítására akkor, ha rendelkeznek erre vonatkozó szakértelemmel. A rendelkezéssel párhuzamosan megindult az igazgatási szakemberek ingatlanközvetítő és ingatlanforgalmi szakértővé történő képzése is. A szabályozás azt a lehetőséget használja ki, hogy a hatóságnak nem kell szakértőt igénybe vennie, amennyiben rendelkezik kellő szakértelemmel az adott kérdésben. Esetünkben azonban egyrészt ez nem csökkenti, hanem növeli a bürokráciát, mivel az ügyintézőket erre ki kell képezni, és kellő gyakorlatot kell szerezniük. Másrészt a hatósági eljárásban az ügyintéző eddigi függetlenségét, objektivitását csökkenti, hiszen a szakkérdés elbírálásakor kikerül a független szakértő az eljárásból, annak minden garanciális elemével és szerepével együtt.

$* * *$

Összegzésként megállapíthatjuk, hogy a fenti szabályozásalapján egyelöre a bürokrácia nyerte a csatát, hiszen, bár a javaslatok iránya jó volt, a megszületett szabályozás aligha vezet a bürokratikus eljárások adminisztratív terhének csökkentéséhez. Ismét bebizonyosodott azonban, hogy az eljárások

\footnotetext{
${ }^{13}$ https://www.nkh.gov.hu/dokumentumtar/pdf-elonezet/-/p/1372680/nyilvantartas-amagyarorszagon-utdijszedoi-utdijszolgaltato-vagy-eets-szolgaltatoi-tevekenyseget-vegzoszervezetekrol 2017. augusztus 4. napján rögzített állapot (a tanulmány közlésének időpontjában is változatlan).

14 2007. évi CXXIII. törvény
} 
elektronizálása, az igazgatás elektronikus fejlesztése - kellő szabályozással - jó eszköz lehet a bürokrácia elleni harcban.

\section{Források jegyzéke:}

- Józsa Zoltán - Bartha Ildikó (2017): A bürokrácia, barát vagy ellenség? Közjavak, III. évf. 2017/2. szám, 3-7. old.

- 2003. évi LXXX. törvény a jogi segítségnyújtásról

- 2007. évi CXXIII. törvény a kisajátításról

- 2013. évi LXVII. törvény az autópályák, autóutak és főutak használatáért fizetendő, megtett úttal arányos díjról

- 2013. évi LXXXIV. törvény egyes törvényeknek a közigazgatási hatósági eljárásokkal, az egyes közhiteles hatósági nyilvántartásokkal összefüggő, valamint egyéb törvények módosításáról

- 2015. évi CCXXII. törvény az elektronikus ügyintézés és a bizalmi szolgáltatások általános szabályairól

- 2016. évi CL. törvény az általános közigazgatási rendtartásról

- 2016. évi XXXII. törvény a közigazgatási bürokráciacsökkentés keretében egyes adminisztratív kötelezettségek megszüntetésével összefüggő törvénymódosításokról

- A Bizottság az európai elektronikus útdíjszedési szolgáltatás és müszaki elemei meghatározásáról szóló, 2009. október 6-i 2009/750/EK határozata

- https://www.edibasics.com/what-is-edi/

- https://www.nkh.gov.hu/dokumentumtar/pdf-elonezet//p/1372680/nyilvantartas-a-magyarorszagon-utdijszedoiutdijszolgaltato-vagy-eets-szolgaltatoi-tevekenyseget-vegzoszervezetekrol 